3. Dorozinsky G.V, Doroshenko T.P, Maslov V.P. Influence of technological factors on sensitivity of analytical devices based on surface plasmon resonance .// Journal of Sensor Technology. 2015; 5: 54-61.

4. Klestova Z.S., Yushchenko A.Yu., Blotskaya O.F., Maslov V.P., Ushenin Yu.V, Dorozinsky G.V., Dorozinska G.V. Eksperymentalno-teoretychne obgruntuvannya rozrobky ekspres metody vyjavlennya enterovirusiv y void metodom poverhnevogo plazmonnogo rezonansu // Innovative Biosystems and Bioengineering. - 2019. - Vol. 3(1). - P.52-60 [in Ukrainian].

5. Maslov V., Ushenin Yu., Dorozinsky G., Klestova Z., Blotskaya O., Yushchenko A., Dorozinska H. Development High Sensitivity Sensors Based on Surface Plasmon Resonance Phenomenon // Confer. Proceed / Igor Sikorsky Kyiv Politechnic Inst. - 2019 IEEE 39 th Intern. Confer. On Electronics and Nanotechnology (ELNANO). - P. 249-252

6. Dorozinska H.V., Turu T.A., Markina O.M., Dorozinsky G.V., Maslov V.P. Influence of Temperature on the Measuring Accuracy of Devices Based on Surface Plasmon Resonance Phenomenon // Modern Instrumentation. - 2018. - Vol. 7. - P. 1-10

Рецензент - В. Л. Коваленко, д. вет. н., професор, ДНКІБШМ.

doi: $10.36359 /$ scivp.2019-20-2.52

\title{
EFEKTYWNOŚĆ WYKORZYSTANIA FERMENTOWANEJ POEKSTRAKCYJNEJ ŚRUTY RZEPAKOWEJ W ŻYWIENIU LOCH
}

\author{
Anna Czech, Martyna Kiesz, Sylwia Kłos \\ Katedra Biochemii i Toksykologii Uniwersytet Przyrodniczy w Lublinie \\ ul. Akadamicka 13 20-950 Lublin, Polska
}

Celem badań była ocena efektywności stosowania fermentowanej poekstrakcyjnej śruty z rzepaku w mieszankach dla loch w okresie ciąży i laktacji na podstawie wskaźników produkcyjnych, wartości wybranych wskaźników odpornościowych, a także zawartości składników mineralnych w siarze i krwi. Doświadczenie przeprowadzono na 40 lochach, przydzielonych równomiernie do dwóch grup żywieniowych tj. grupy kontrolnej (K) oraz grupy doświadczalnej (D) żywionej mieszanka z 9\% udziatem fermentowanej poekstrakcyjnej śruty rzepakowej (FR) $w$ miejsce poekstrakcyjne śruty sojowej. Doświadczenie rozpoczęto $w$ dniu potwierdzenia ciąży metoda ultrasonografii (USG) (ok. 3 tygodnia ciaży) a zakończono $w 27$ dniu laktacji (odsadzenie prosiat).

Efektywność żywienia świń oceniano na podstawie liczebności miotu i masy ciała prosiat przy urodzeniu i odsadzeniu, zużycia paszy oraz zdrowia zwierząt. W czasie calego okresu prowadzono obserwacje zdrowia i kondycji zwierzat. Podczas trwania doświadczeń kontrolowano ilościowo spożycie pasz. Próbki krwi, pobrano od zwierząt w następujacych okresach: wysoka ciąza (ok. 100 dzień ciąży), laktacja (ok. 27 dzień laktacji), a także od prosiat ok. 27 dzień życia (koniec laktacji). $W$ petnej krwi na aparacie ABACUS-Vet oznaczono liczbe krwinek biatych (WBC) i procentowy udziat limfocytów (LIM). Obliczono również liczbowy stosunek granulocytów do limfocytów (G:L). Koncentracja przeciwcial IgA, IgG w osoczu krwi oraz w siarze loch oznaczano ilościowo Podstawowy skład chemiczny siary oznaczano klasycznymi metodami przy pomocy aparatu MilkoScan 104 (A/S N. Fooss Electric, Dania). Zawartość wapnia, żelaza, miedzi i cynku w paszy, krwi $i$ siarze oznaczono metoda spektometrii absorpcji atomowej (ASA), a zawartość fosforu ogólnego w paszy wedlug metody Fiske-Subbarowa [12]. Fermentacja poekstrakcyjnej śruty rzepakowej jest 
skutecznym sposobem redukcji substancji antyżywieniowych (fosforu fitynowego) $w$ mieszankach paszowych oraz stymulacji układu odpornościowego, co w konsekwencji wptywa na poprawe jakości siary u loch otrzymujacych pasze z komponentem fermentowanym zmniejszajac tym samym nasilenie biegunek $i$ śmiertelność prosiąt. Uzyskane wyniki potwierdzaja, więc że udziat $w$ mieszankach komponentu fermentowanego istotnie wptywa na poprawę wartości wskaźników produkcyjnych, prowadzac do wzrostu liczby prosiąt $w$ miocie i masy miotu $w 28$ dniu życia, a także na stymulacje układu immunologicznego, wpływając m.in. na sekrecję wydzielniczych immunoglobulin IgG i IgA u loch oraz prosiat. Udziat fermentowanej poekstrakcyjnej śruty rzepakowej w mieszankach dla loch $w$ okresie ciąży i laktacji wpływa również na lepsze wykorzystanie składników mineralnych tj. fosfor, wapń, miedź i żelazo z mieszanek paszowych.

Słowa kluczowe: LOCHY, FERMENTOWANA POEKSTRAKCYJNA ŚRUTA RZEPAKOWA, EFEKTY PRODUKCYJNE, KREW, SIARA.

Zarówno śruta rzepakowa jak i sojowa są ważnymi źródłami białka, które mogą być wykorzystane do opracowania odpowiednio zbilansowanej mieszanki paszowej dla zwierząt gospodarskich. Jednak wykorzystanie ich zwłaszcza w żywieniu zwierząt monogastrycznych (drób, trzoda chlewna) utrudnione jest przez obecność w nich wielu czynników antyżywieniowych, takich jak glukozynolany, taniny, kwas fitynowy czy inne [1]. Na antyodżywcze działanie tych składników narażone są przede wszystkim młode osobnik, które nie mają $\mathrm{w}$ pełni wykształconych funkcji obronnych organizmu.

W celu rozwiązania tej sprzeczności pomiędzy wysoką wartością odżywczą i niskim stopniem wykorzystania śruty rzepakowej czy sojowej, stosowane są metody detoksykacji, a także ekstrakcji, separacji śruty rzepakowej czy sojowej [2]. Jedną z takich metod jest poddanie śruty działaniu mikroorganizmów (proces fermentacji), które jako źródło enzymów takich jak: glukozydazy, amylazy, celulazy, chitynazy, inulinase, fitazy, ksylanazy, esterazy, tanazy, inwertazy lub lipazy, mogą skutecznie hydrolizować białka rzepaku czy soi, a przede wszystkim rozkładać substancje toksyczne [3]. Ponadto fermentacja wywołując podział strukturalny ścian komórkowych zbóż uwalnia i/lub indukuje syntezę różnych związków bioaktywnych w tym przede wszystkim przeciwutleniaczy [4]. Fermentowane komponenty paszowe w formie płynnej (system żywienia na mokro) wykorzystywane są w żywieniu zwierząt monogastrycznych od wielu lat [5; 6], jednak ze względu na trudności jakie związane są z podawaniem takiej formy paszy dla drobiu oraz z mnogością gospodarstw hodujących trzodę chlewną $w$ systemie tzw. na sucho intersujące byłoby przeanalizowanie skuteczności stosowania fermentowanej śruty rzepakowej w miejsce śruty sojowej w żywieniu loch w okresie ciąży i laktacji. Skuteczność stosowania tego rodzaju komponentów paszowych będzie analizowana pod kątem efektów produkcyjnych, a także badań krwi. W zawiązku z powyższym celem badań była ocena efektywności stosowania fermentowanej poekstrakcyjnej śruty z rzepaku w mieszankach dla loch w okresie ciąży i laktacji na podstawie wskaźników produkcyjnych, wartości wybranych wskaźników odpornościowych, a także zawartości składników mineralnych w siarze i krwi.

Materiał i metody. Materiał doświadczalny stanowiło 40 loch (Yorkshire kryte knurami Danish Landrace) pochodzącym z tej samej firmy genetycznej, które przydzielono równomiernie do dwóch grup żywieniowych tj. grupę kontrolną (K) oraz grupę doświadczalną (D) żywioną mieszanką z udziałem fermentowanej poekstrakcyjnej śruty rzepakowej (FR). Od momentu stwierdzenia ciąży aż do 27 dnia laktacji, lochy z grupy doświadczalnej otrzymywały mieszankę z 9\% udziałem FR. Doświadczenie rozpoczęto $\mathrm{w}$ dniu potwierdzenia ciąży metodą ultrasonografii (USG) (ok. 3 tygodnia ciąży). Lochy z grupy kontrolnej żywiono mieszankami standardowymi na okres ciąży oraz laktacji (Tabela 1). Zawartość składników pokarmowych w zależności od okresu produkcyjnego była zgodna z zaleceniami żywieniowymi i wartościami pokarmowymi pasz dla świń [7], a pasze fermentowane wprowadzono zamiast standardowej poekstrakcyjnej śruty sojowej (Tabela 1). Zwierzęta utrzymane 
będą zgodnie z warunkami obowiązującymi na Fermie i odpowiadających standardowym warunkom dobrostanu zwierząt.

Czynności doświadczalne. Efektywność żywienia świń oceniano na podstawie liczebności miotu i masy ciała prosiąt przy urodzeniu i odsadzeniu, zużycia paszy oraz zdrowia zwierząt. Prosięta były ważone indywidualnie przy urodzeniu, a następnie w 28 dniu (odsadzenie). W czasie całego okresu prowadzono obserwacje zdrowia i kondycji zwierząt. Podczas trwania doświadczeń kontrolowano ilościowo spożycie pasz.

W każdym okresie żywienia pobrano dwukrotnie próbki pasz do analiz: niska ciąża ok. 35-40 dnia oraz mieszanka dla loch w wysokiej ciąży i laktacji. W paszy oznaczono: suchą masę, popiół surowy, białko ogólne, tłuszczu surowego, włókno surowe [8]. W paszy oznaczono również ilość fosforu fitynowego według Oberleasa [9] oraz zawartość kwasu mlekowego wg Taylor [10] i glukozynolanów wg PN-ISO 10633-1:2000 [11].

Próbki krwi, pobrano od zakolczykowanych zwierząt w następujących okresach: wysoka ciąża (ok. 107 dzień ciąży), laktacja (ok. 21 dzień laktacji), a także od prosiąt ok. 27 dzień życia (koniec laktacji). Krew pobierano jednorazowo w wyżej wymienionych terminach. Krew była pobierana zawsze od tych samych zwierząt. Na dwanaście godzin przed pobraniem krwi zwierzęta nie miały dostępu do paszy. Krew pobierano do heparynizowanych probówek o objętości $10 \mathrm{ml} \mathrm{z}$ żyły jarzmowej przez lekarza weterynarii. W pełnej krwi na aparacie ABACUS-Vet oznaczono liczbę krwinek białych (WBC) i procentowy udział limfocytów (LIM). Obliczono również liczbowy stosunek granulocytów do limfocytów (G:L).

Tabela 1

Skład surowcowy (\% masy pow. suchej) mieszanek dla loch

\begin{tabular}{|c|c|c|c|c|}
\hline \multirow{2}{*}{ Wyszczególnienie } & \multicolumn{2}{|c|}{ Ciąża niska } & \multicolumn{2}{|c|}{ Ciąża wysoka/laktacja } \\
\hline & $\mathrm{K}$ & $\mathrm{D}$ & $\mathrm{K}$ & $\mathrm{D}$ \\
\hline Pszenica & & & 36,0 & 36,0 \\
\hline Pszenżyto & 30,0 & 30,0 & & \\
\hline Jęczmień & 30,0 & 27,0 & 37,3 & 34,7 \\
\hline Owies & 29,32 & 29,32 & 4,0 & 4,0 \\
\hline Poekstrakcyjna ś ruta sojowa & 6,0 & 0,0 & 16,0 & 10,0 \\
\hline Olej rzepakowy & 1,0 & 1,0 & 2,0 & 2,0 \\
\hline Mieszanka uzupełniająca $^{1}$ & 0,12 & 0,12 & 0,24 & 0,24 \\
\hline Sól pastewna & 0,4 & 0,4 & 0,4 & 0,4 \\
\hline Kreda paszowa & 0,7 & 0,7 & 0,7 & 0,7 \\
\hline Fosforan 1-wapniowy & 0,26 & 0,26 & 0,26 & 0,26 \\
\hline L-Lizyna & 0,12 & 0,12 & 0,12 & 0,12 \\
\hline DL-Metionina & 0,08 & 0,08 & 0,08 & 0,08 \\
\hline Premiks mineralno- witaminowy ${ }^{2}$ & 2,0 & 2,0 & 2,5 & 2,5 \\
\hline Zakwaszacz $^{3}$ & - & - & 0,4 & - \\
\hline $\mathrm{FR}^{4}$ & - & 9,0 & - & 9,0 \\
\hline
\end{tabular}

${ }^{1}$ Mieszanka uzupełniająca: Skład w 1 kg: otręby pszenne, chlorek sodu, fosforan wapnia. wapń $145000 \mathrm{mg}$, sód 10000 $\mathrm{mg}$, fosfor $5500 \mathrm{mg}$, białko surowe 2,8 \%, oleje i tłuszcz surowy 0,4\%, włókno surowe 1,6 \%, popiół surowy 80\%, witamina A 1350000 j.m., witamina B $200 \mathrm{mg}$, witamina B2 $800 \mathrm{mg}$, witamina B5 $1200 \mathrm{mg}$, witamina B6 $500 \mathrm{mg}$, witamina B9 $800 \mathrm{mg}$, witamina B12 $55 \mathrm{mg}$, witamina C $10000 \mathrm{mg}$, witamina D3 $25000 \mathrm{mg}$, witamina E $6000 \mathrm{mg}$, witamina H $300 \mathrm{mg}$, witamina K3 $270 \mathrm{mg}$, witamina PP $2000 \mathrm{mg}$, cholina $3500 \mathrm{mg}$, żelazo $4000 \mathrm{mg}$, miedź $500 \mathrm{mg}$, cynk $4000 \mathrm{mg}$, mangan $2000 \mathrm{mg}$, jod $35 \mathrm{mg}$, selen $5 \mathrm{mg}$, wyciąg z glistnika jaskółcze ziele $5 \%$, wyciąg z lebiodki pospolitej $4 \%$,

${ }^{2}$ Premiks mineralno-witaminowy (w $1 \mathrm{~kg}$ ): węglan wapnia, chlorek sodu, fosforan wapnia. witamina A 520000j.m., witamina D3 80 000j.m., witamina E 800mg, witamina K3 100mg, witamina B1 80mg, witamina B2 $280 \mathrm{mg}$, witamina B6 $200 \mathrm{mg}$, witamina B9 $60 \mathrm{mg}$, witamina B12 $1000 \mathrm{mcg}$, witamina H 10 000mcg, witamina PP 800mg, witamina B5 600mg, cholina 15 000mg, żelazo 4 000mg, miedź 800mg, cynk 4 000mg, mangan 2 000mg, selen 10mg, jod 30mg, L-lizyna 30 000mg, L-metionina $10000 \mathrm{mg}$, treonina $10000 \mathrm{mg}$

${ }^{3}$ Zakwaszacz (W $1 \mathrm{KG}$ ): materiały paszowe: dwutlenek krzemu (11.7.3), chlorek sodu (11.4.1) (NaCl). Dodatki

Technologiczne: Regulatory kwasowości: kwas ortofosforowy, (1a338) 32\%, kwas cytrynowy (E330) 11\%, kwas fumarowy (E297) 5\%, kwas propionowy (E280) 4,5\%, kwas mrówkowy (E236) 4,5\%.

${ }^{4} \mathrm{FR}^{-}$fermentowana poekstrakcyjna śruta rzepakowa 
Po 6 h po porodzie od 6 loch z grupy pobrano próbki siary. Bezpośrednio po pobraniu próbki poddano analizie. Koncentracja przeciwciał IgA, IgG w osoczu krwi oraz w siarze loch oznaczano ilościowo za pomocą specyficznego kitu dla świń IgA, IgG techniką ELISA (Bethyl Laboratories, Inc., Montgomery, TX). Podstawowy skład chemiczny siary oznaczano klasycznymi metodami przy pomocy aparatu Milko-Scan 104 (A/S N. Fooss Electric, Dania). Zawartość wapnia, żelaza, miedzi i cynku w paszy, krwi i siarze oznaczono metodą spektometrii absorpcji atomowej (ASA), a zawartość fosforu ogólnego w paszy według metody Fiske-Subbarowa [12].

Analiza statystyczna. Uzyskane dane liczbowe poddano analizie statystycznej, określając wartości średnie i błędy statystyczne z wykorzystaniem programu Statistica wersja 6,1. Istotność różnic między średnimi wyznaczono testem analizy wariancji dwuczynnikowej ANOVA, z wykorzystaniem testu Tukeya, przyjmując poziom istotności 0,05 i 0,01 .

Omówienie wyników i dyskusja. Ze względu na wysoką zawartość aminokwasów egzogennych $\mathrm{w}$ tym bogatą $\mathrm{w}$ siarkę metioninę oraz relatywnie dużą zawartość fosforu, śruta rzepakowa jest dobrym składnikiem białkowym paszy dla zwierząt monogastrycznych. Badania wskazują, że może ona częściowo zastąpić nawet śrutę sojową w żywieniu loch i prosiąt [13]. Ograniczeniem jej stosowania jest jednak obecność wielu składników antyodżywczych takich jak glukozynolany, garbniki czy związki fitynowe [14], które wpływają m.in. na obniżenie strawności i wykorzystanie składników odżywczych. Dowiedziono, że fermentacja jest skutecznym sposobem redukcji niepożądanych substancji w śrucie rzepakowej, nawet o ponad 80\% [15]. Taki efekt był widoczny w przeprowadzonym doświadczeniu (Tabela 2).

Zawartość składników pokarmowych i substancji bioaktywnych w 1 kg mieszanki dla loch

Tabela 2

\begin{tabular}{|l|c|c|c|c|}
\hline \multirow{2}{*}{ Wyszczególnienie } & \multicolumn{2}{c|}{ Ciąża niska } & \multicolumn{2}{c|}{ Ciąża wysoka/laktacja } \\
\cline { 2 - 4 } & $\mathrm{K}$ & $\mathrm{D}$ & $\mathrm{K}$ & $\mathrm{D}$ \\
\hline Sucha masa, g & 882 & 883 & 888 & 886 \\
\hline Popiół surowy, g & 50,54 & 49,44 & 51,88 & 50,98 \\
\hline Białko ogólne, g & 151,0 & 151,2 & 170,2 & 171,0 \\
\hline Tłuszcz surowy, g & 33,1 & 33,0 & 27,2 & 27,3 \\
\hline Fosfor ogólny, g & 5,11 & 5,15 & 5,66 & 5,61 \\
\hline Fosfor fitynowy, g & $3,09^{\mathrm{a}}$ & $2,40^{\mathrm{b}}$ & $3,68^{\mathrm{a}}$ & $2,21^{\mathrm{b}}$ \\
\hline Wapń, g & 7,55 & 7,23 & 8,53 & 8,66 \\
\hline Cynk, mg & 141,9 & 143,2 & 143,3 & 144,0 \\
\hline Miedź, mg & 18,01 & 18,11 & 20,04 & 20,09 \\
\hline Żelazo, mg & 144,9 & 146,3 & 165,9 & 165,5 \\
\hline Glukozynolany, $\mu \mathrm{mol} \mathrm{g}^{-1}$ & 0,001 & 0,002 & 0,002 & 0,003 \\
\hline Kwas mlekowy, mmol 1 ${ }^{-1}$ & $16,88^{\mathrm{b}}$ & $45,96^{\mathrm{a}}$ & $14,47^{\mathrm{b}}$ & $80,02^{\mathrm{a}}$ \\
\hline
\end{tabular}

$\mathrm{a}, \mathrm{b}$ - wartości w wierszach różnią się istotnie przy $\mathrm{P} \leq 0,05$

Mieszanki z udziałem komponentu fermentowanego (grupa D) cechowały się istotnie niższym w stosunku do grupy kontrolnej poziomem glukozynolanów. Również zawartość fosforu fitynowego w mieszankach z udziałem komponentu fermentowanego była istotnie niższa niż w grupie kontrolnej (Tabela 2), co wg Wang i wsp. [13] można przypisać mikroorganizmom towarzyszącym procesowi fermentacji, które są źródłem enzymu fitazy, odpowiedzialnego za rozkład kompleksów fitynowych [15]. Wg SchoÈne i wsp. [16] niska zawartość składników antyodżywczych w mieszankach paszowych dla loch $\mathrm{w}$ okresie laktacji koresponduje $\mathrm{z}$ obniżeniem ich ilości $\mathrm{W}$ mleku. Prawdopodobnie efektem tego, w przeprowadzonym doświadczeniu, było uzyskanie u nowo narodzonych prosiąt pochodzących od loch żywionych mieszanką z udziałem FR poprawy ich kondycji tj. obniżenie nasilenia biegunek $(\mathrm{P}=0,004)$ oraz zmniejszenie liczby dni biegunkowych $(\mathrm{P}$ $=0,010$ ), a także obniżenie śmiertelności prosiąt (Tabela 3).

Wzrost liczby żywo urodzonych prosiąt $(\mathrm{P}=0,043)$ oraz liczby prosiąt $\mathrm{w} 28$ dniu życia $(\mathrm{P}=$ 0,015) od loch żywionych mieszanką z udziałem FR (Tabela 3) mogła wynikać, również ze stymulacji procesów odpornościowych w organizmie matki, na co wskazuje wzrost miana immunoglobulin, a także składników pokarmowych w siarze (Tabela 4). 
Wskaźniki produkcyjne loch oraz wskaźniki odchowu prosiąt

\begin{tabular}{|c|c|c|c|}
\hline \multirow{3}{*}{ Wskaźnik } & \multirow{2}{*}{\multicolumn{2}{|c|}{$\begin{array}{c}\text { Grupa żywieniowa } \\
\text { Pierwiastki }\end{array}$}} & \multirow[t]{3}{*}{$\mathrm{P}_{\text {value }}$} \\
\hline & & & \\
\hline & $\mathrm{K}$ & $\mathrm{D}$ & \\
\hline Liczba prosiąt w miocie, ogółem & 14,53 & 14,85 & 0,065 \\
\hline Liczba prosiąt żywo urodzonych & 13,32 & 14,20 & 0,043 \\
\hline Liczba prosiąt w 28 dniu życia & 11,25 & 13,22 & 0,015 \\
\hline Masa prosiąt przy urodzeniu, $\mathrm{kg}$ & 1,25 & 1,30 & 0,152 \\
\hline Masa prosiąt w 28 dniu życia, kg & 6,08 & 5,83 & 0,104 \\
\hline Masa miotu w 28 dniu życia, kg & 72,55 & 75,82 & 0,033 \\
\hline Śmiertelność do 28 dnia życia, \% & 12,93 & 6,72 & 0,002 \\
\hline Nasilenie biegunek, $\%$ & 22,66 & 10,25 & 0,004 \\
\hline Dni biegunkowe & 5,57 & 2,97 & 0,010 \\
\hline Konsystencja kału, pkt & 2,52 & 1,65 & 0,033 \\
\hline
\end{tabular}

W siarze loch otrzymujących mieszankę z udziałem komponentu fermentowanego (grupa D) zanotowano istotnie wyższą zawartość białka ogólnego, tłuszczu całkowitego, a także składników mineralnych tj. fosforu, wapnia, miedzi i żelaza. Zanotowano również wyższe miano immunoglobulin IgG i IgA oraz niższą liczbę komórek somatycznych w stosunku do grupy kontrolnej (K), co może świadczyć o pobudzeniu procesów odpornościowych (Tabela 4). Na takie zależności zwrócili uwagę również Bontempo i wsp. [17].

Miano immunoglobulin i zawartość wybranych składników chemicznych w siarze loch

Tabela 4

\begin{tabular}{|c|c|c|c|}
\hline \multirow{3}{*}{ Wskaźnik } & \multirow{2}{*}{\multicolumn{2}{|c|}{$\begin{array}{c}\text { Grupa żywieniowa } \\
\text { Pierwiastki }\end{array}$}} & \multirow{3}{*}{$\mathrm{P}_{\text {value }}$} \\
\hline & & & \\
\hline & $\mathrm{K}$ & $\mathrm{D}$ & \\
\hline Sucha masa; \% & 22,88 & 23,41 & 0,098 \\
\hline Białko ogólne; \% & 13,29 & 14,88 & 0,035 \\
\hline Tłuszcz całkowity; $\%$ & 2,99 & 3,62 & 0,045 \\
\hline Liczba komórek somatycznych & 2231,0 & 1989,1 & 0,041 \\
\hline $\mathrm{IgG} ; \mathrm{mg} \mathrm{ml}^{-1}$ & 44,65 & 58,43 & 0,011 \\
\hline $\operatorname{IgA} ; \mathrm{mg} \mathrm{ml}^{-1}$ & 9,04 & 13,61 & 0,006 \\
\hline Fosfor; mmol 1-1 & 28,28 & 40,11 & 0,028 \\
\hline Wapń; mmol l-1 & 19,76 & 24,19 & 0,033 \\
\hline Miedź; $\mu \mathrm{mol} \mathrm{1^{-1 }}$ & 49,06 & 60,44 & 0,045 \\
\hline Cynk; $\mu \mathrm{mol} \mathrm{l}^{-1}$ & 176,7 & 180,6 & 0,227 \\
\hline Żelazo; $\mu \mathrm{mol} \mathrm{l}^{-1}$ & 51,76 & 67,34 & 0,040 \\
\hline
\end{tabular}

Wg Scholten i wsp. [18] proces fermentacji dzięki wzbogaceniu paszy w krótkołańcuchowe kwasy tłuszczowe, witaminy i enzymy, stymuluje środowisko przewodu pokarmowego do rozwoju korzystnej mikroflory jelitowej (m.in. pałeczki kwasu mlekowego Lactobacillus czy Bifidobacterium), co wpływa korzystnie na aktywację reakcji odpornościowych. Właśnie obecność bakterii mlekowych, a tym samym dużej ilości kwasu mlekowego, czy innych krótkołańcuchowych kwasów organicznych w paszy fermentowanej powoduje zakwaszanie treści jelita, zwiększenie aktywności enzymów jelitowych, ale przede wszystkim stymulację miejscowej odporności w obrębie błony śluzowej przewodu pokarmowego [19]. Pobudzenie procesów odpornościowych, które wystąpiło u loch zarówno w okresie ciąży jak i laktacji żywionych mieszanką z udziałem fermentowanej poekstrakcyjnej śruty rzepakowej i prosiąt pochodzących od tych loch, skutkowało wzrostem ilości wytwarzanych w szpiku kostnym a następnie przedostających się do krwi limfocytów. W przeprowadzonym doświadczeniu udział $\mathrm{w}$ mieszankach komponentu fermentowanego (grupa D) przyczynił się właśnie, do istotnego wzrostu ilości limfocytów (LIM) oraz obniżenia stosunku granulocytów do limfocytów (GRA/LIM) u loch w okresie ciąży i laktacji (Tabela 5). Natomiast $\mathrm{u}$ prosiąt pochodzących od loch żywionych mieszanką $\mathrm{z}$ udziałem komponentu 
fermentowanego odnotowano zarówno podwyższenie ilości leukocytów $(\mathrm{P}=0,033)$ jak i limfocytów $(\mathrm{P}=0,007)$ oraz zmniejszony stosunek GRA/LIM $(\mathrm{P}=0,031)$ (Tabela 5$)$.

Wybrane wskaźniki immunologiczne krwi loch

\begin{tabular}{|c|c|c|c|}
\hline \multirow{3}{*}{ Wskaźnik } & \multirow{2}{*}{\multicolumn{2}{|c|}{$\begin{array}{c}\text { Grupa żywieniowa } \\
\text { Pierwiastki }\end{array}$}} & \multirow{3}{*}{$\mathrm{P}_{\text {value }}$} \\
\hline & & & \\
\hline & $\mathrm{K}$ & $\mathrm{D}$ & \\
\hline \multicolumn{4}{|c|}{ Lochy w okresie ciąży } \\
\hline WBC; $10^{9} 1^{-1}$ & 14,99 & 15,54 & 0,065 \\
\hline LIM; \% & 60,93 & 74,63 & $<0,001$ \\
\hline GRA/LIM & 0,595 & 0,363 & $<0,001$ \\
\hline $\mathrm{IgG} ; \mathrm{mg} \mathrm{ml}^{-1}$ & 10,47 & 12,94 & 0,016 \\
\hline $\mathrm{IgA} ; \mathrm{mg} \mathrm{ml}^{-1}$ & 1,23 & 2,02 & 0,048 \\
\hline \multicolumn{4}{|c|}{ Lochy w okresie laktacji } \\
\hline WBC; $10^{9} 1^{-1}$ & 12,35 & 14,77 & 0,050 \\
\hline LIM; \% & 53,55 & 63,185 & $<0,001$ \\
\hline GRA/LIM & 0,866 & 0,584 & $<0,001$ \\
\hline $\mathrm{IgG} ; \mathrm{mg} \mathrm{ml}^{-1}$ & 4,78 & 5,91 & 0,044 \\
\hline $\operatorname{IgA} ; \mathrm{mg} \mathrm{ml}^{-1}$ & 1,15 & 1,99 & 0,039 \\
\hline \multicolumn{4}{|c|}{ Prosięta } \\
\hline WBC; $10^{9} 1^{-1}$ & 15,15 & 18,28 & 0,033 \\
\hline LIM; \% & 61,05 & 69,55 & 0,007 \\
\hline GRA/LIM & 0,615 & 0,333 & 0,031 \\
\hline IgG; mg ml-1 & 5,62 & 6,64 & 0,026 \\
\hline $\operatorname{IgA} ; \mathrm{mg} \mathrm{ml}^{-1}$ & 0,215 & 0,360 & 0,017 \\
\hline
\end{tabular}

Wzrostowi ilości limfocytów towarzyszył istotny wzrost ilości immunoglobulin wydzielniczych IgA i IgM (Tabela 5), produkowanych przez ich aktywne postacie tzn. limfocyty B (plazmocyty), stymulujących powstawanie i utrzymywanie antygenowo swoistej tolerancji immunologicznej na antygeny pokarmowe [20]. Obie te immunoglobuliny są ściśle ze sobą powiązane i zależą od ciągłej stymulacji komórek mukoidalnego układu odpornościowego przez komensalną florę jelitową, w tym także przez bakterie kwasu mlekowego (Lactobacillus), dostarczane np. z paszą fermentowaną [20]. Reakcja ta zarówno u prosiąt pochodzących od loch otrzymujących mieszankę z komponentem fermentowanym, była zgodna z badaniami Cai i wsp. [21], którzy wykorzystali do procesu fermentacji bakterie Lactobacillus fermentum. Jest to bardzo korzystne dla prosiąt, ponieważ ich mikroflora jelitowa nie jest jeszcze odpowiednio ukształtowana. W odróżnieniu od jałowego zwykle środowiska wewnątrzmacicznego, nowo urodzone prosięta nie posiadają własnej odporności swoistej chroniącej je przed zakażeniami środowiskowymi. Dlatego też są grupą najbardziej potrzebującą pobudzenia/wspomagania procesów odpornościowych [22, 23]. Immunoglobuliny znajdujące się $\mathrm{w}$ siarze loch transportowane są niespecyficzną pinocytozą $\mathrm{w}$ enterocytach jelita cienkiego prosiąt [24].

Tym samym poprawa statusu odpornościowego matki, wpływa na status jej potomstwa. $\mathrm{Na}$ takie zależności wskazują badania Salmon i wsp. [25] oraz wyniki przeprowadzonego doświadczenia (Tabela 4). Jak już wcześniej wspomniano w siarze loch żywionych mieszanką z udziałem fermentowanej poekstrakcyjnej śruty rzepakowej zanotowano istotny wzrost ilości immunoglobulin IgA i IgG, co korespondowało z ich wyższym mianem w osoczu krwi i było zgodne z badaniami Rooke i Bland [26]. Na wzrost ilości immunoglobulin u świń otrzymujących paszę fermentowaną (płynną) wskazują także badania Mizumach i wsp. [27].

Udział w mieszankach dla loch komponentu fermentowanego był podyktowany również chęcią poprawy dostępności składników pokarmowych w tym elementów mineralnych z mieszanek paszowych [28, 29], co zostało potwierdzone w przeprowadzonych badaniach. Dodatek fermentowanej śruty rzepakowej (grupa D) w żywieniu ciężarnych i laktujących loch miał istotny 
wpływ na wzrost zawartości fosforu, wapnia, miedzi i żelaza w osoczu krwi zarówno loch jak i prosiąt pochodzących od tych loch (Tabela 6).

Zawartość składników mineralnych w osoczu krwi loch i prosiąt

\begin{tabular}{|c|c|c|c|}
\hline \multirow{3}{*}{ Wskaźnik } & \multirow{2}{*}{\multicolumn{2}{|c|}{$\begin{array}{c}\text { Grupa żywieniowa } \\
\text { Pierwiastki }\end{array}$}} & \multirow{3}{*}{$\mathrm{P}_{\text {value }}$} \\
\hline & & & \\
\hline & $\mathrm{K}_{1}$ & $\mathrm{FR}_{1}$ & \\
\hline \multicolumn{4}{|c|}{ Lochy w okresie ciąży } \\
\hline Fosfor; mmol l-1 & 1,22 & 1,81 & $<0,001$ \\
\hline Wapń; mmol l-1 & 2,17 & 2,74 & 0,043 \\
\hline Miedź; $\mu \mathrm{mol} 1^{-1}$ & 24,33 & 30,02 & 0,017 \\
\hline Cynk; $\mu \mathrm{mol} \mathrm{1} 1^{-1}$ & 9,11 & 9,54 & 0,216 \\
\hline Żelazo; $\mu \mathrm{mol} \mathrm{l}^{-1}$ & 14,88 & 20,11 & 0,011 \\
\hline \multicolumn{4}{|c|}{ Lochy w okresie laktacji } \\
\hline Fosfor; mmol l-1 & 1,44 & 2,22 & 0,012 \\
\hline Wapń; mmol l-1 & 2,64 & 2,79 & 0,140 \\
\hline Miedź; $\mu \mathrm{mol} \mathrm{1^{-1 }}$ & 13,01 & 14,95 & 0,049 \\
\hline Cynk; $\mu \mathrm{mol} \mathrm{l}^{-1}$ & 17,77 & 17,22 & 0,069 \\
\hline Żelazo; $\mu \mathrm{mol} \mathrm{l}^{-1}$ & 18,58 & 22,93 & 0,018 \\
\hline \multicolumn{4}{|c|}{ Prosięta } \\
\hline Fosfor; mmol 1-1 & 1,83 & 2,38 & 0,015 \\
\hline Wapń; mmol l-1 & 2,58 & 3,44 & 0,036 \\
\hline Miedź; $\mu \mathrm{mol} \mathrm{1^{-1 }}$ & 19,54 & 24,31 & 0,025 \\
\hline Cynk; $\mu \mathrm{mol} \mathrm{l}^{-1}$ & 7,68 & 9,58 & 0,016 \\
\hline Żelazo; $\mu \mathrm{mol} \mathrm{l} \mathrm{l}^{-1}$ & 26,89 & 33,33 & 0,026 \\
\hline
\end{tabular}

Uzyskany wzrost zawartości fosforu w osoczu krwi ciężarnych i laktujących loch żywionych mieszanką z udziałem fermentowanej śruty rzepakowej (grupa D), a także w osoczu krwi ich prosiąt był prawdopodobnie wynikiem wzrostu ilości fosforu niefitynowego w podawanych mieszankach (Tabela 2), co jest zgodne z badaniami El-Batal i Karem [30]. Na wzrost przyswajalności fosforu u zwierząt otrzymujących paszę na bazie fermentowanej kukurydzy wskazują badania Stein i wsp. [31]. Obok fosforu w osoczu krwi prosiąt pochodzących od loch otrzymujących mieszanki z udziałem paszy fermentowanej zanotowano również wyższą zawartość wapnia. Powodem takiego efektu, podobnie jak w przypadku fosforu, była prawdopodobnie wyższa ilość fitazy syntetyzowanej przez mikroorganizmy powstałe w wyniku procesu fermentacji [32]. Obecność fitazy spowodowała uwolnienie $\mathrm{z}$ połączeń chelatowych m.in. fosforu i wapnia, dzięki czemu zwiększyła się ich dostępność [33]. Takie wyjaśnienie potwierdzili Xu i wsp. [13], którzy wskazali, że istnieje kilka mikroorganizmów powstających w czasie fermentacji śruty rzepakowej, które wytwarzają fitazę mikrobiologiczną. Badania Czech i Greli [34] potwierdziły skuteczność działania fitazy w żywieniu loch w okresie ciąży i laktacji, czego dowodem był wzrost zawartości składników mineralnych w tym przede wszystkim fosforu i wapnia w siarze i mleku.

Równolegle ze wzrostem zawartości fosforu i wapnia w osoczu krwi loch otrzymujących mieszankę z udziałem komponentu fermentowanego, a także prosiąt pochodzących od tych loch odnotowano wzrost koncentracji żelaza, a w przypadku loch w okresie ciąży i laktacji również miedzi. Jest to związane m.in. z obecnością wspomnianej fitazy, a także z obecnością kwasu mlekowego, który wspomaga działanie fitazy i wchłanianie składników pokarmowych w jelicie cienkim [35]. Ponadto na poprawę dostępności składników mineralnych mogła wpłynąć obecność innych pozakomórkowych enzymów degradacyjnych pochodzenia mikrobiologicznego (pochodzących z procesu fermentacji) takich jak celulazy, hemicelulazy, hydrolazy glikozydowe, proteazy, peroksydazy, a także białek pofermentacyjnych [32]. Enzymy hydrolizujące frakcje polisacharydów nieskrobiowych (NSP) wg Juanpere i wsp. [35], mogą przyczyniać się do stworzenia lepszych warunków działania fitazy mikrobiologicznej w żołądku i jelitach. W dostępnym 
piśmiennictwie wiele jest badań potwierdzających rolę fitazy oraz enzymów rozkładających NSP w poprawie absorpcji składników odżywczych i mineralnych paszy [37]. Czech i wsp. [38] zwrócili uwagę na zwiększenie koncentracji żelaza w osoczu krwi loch w grupach, w których zastosowano fitazę oraz preparat wieloenzymatyczny (w skład, którego wchodziła fitaza mikrobiologiczna i enzymy hydrolizujące frakcje polisacharydów nieskrobiowych).

\title{
P O D S U M O W A N I E
}

Fermentacja poekstrakcyjnej śruty rzepakowej jest skutecznym sposobem redukcji substancji antyżywieniowych (fosforu fitynowego) w mieszankach paszowych oraz stymulacji układu odpornościowego, co w konsekwencji wpływa na poprawę jakości siary loch otrzymujących pasze z komponentem fermentowanym zmniejszając tym samym nasilenie biegunek i śmiertelność prosiąt. Uzyskane wyniki potwierdzają, więc że udział w mieszankach komponentu fermentowanego istotnie wpływa na poprawę wartości wskaźników produkcyjnych, prowadząc do wzrostu liczby prosiąt w miocie i masy miotu w 28 dniu życia, a także na stymulacje układu immunologicznego, wpływając m.in. na sekrecję wydzielniczych immunoglobulin $\operatorname{IgG}$ i $\operatorname{IgA} u$ loch oraz prosiąt. Udział fermentowanej poekstrakcyjnej śruty rzepakowej w mieszankach dla loch w okresie ciąży i laktacji wpływa również na leprze wykorzystanie składników mineralnych tj. fosfor, wapń, miedź i żelazo z mieszanek paszowych.

Reasumując, można stwierdzić, że zastosowanie w mieszankach dla loch fermentowanej poekstrakcyjnej śruty rzepakowej przynosi poprawę wskaźników krwi świadczących o stanie zdrowia ich i ich potomstwa, co jest bardzo pożądane w tym strategicznym okresie chowu świń.

\section{ЕФЕКТИВНІСТЬ ВИКОРИСТАННЯ ФЕРМЕНТОВАНОГО ПІСЛЯ ЕКСТРАКЦЇ̈ РІПАКОВОГО ШРОТУ В ГОДІВЛІ СВИНОМАТОК}

\author{
Чех Анна, Кєш Мартіна, Клос Сильвія \\ Катедра Біохімії та Токсикології Природничого Університету в Любліні, \\ вул. Академіцка, 13 20-950 Люблін, Польща
}

\section{А Н О Т А Ц І Я}

Метою досліджень була оцінка ефективності застосування ферментованого після екстракції шроту ріпака в кормових сумішах для свиноматок у період супоросності та лактації за результатами продуктивності, вибраними показниками імунітету, а також вмістом мінеральних елементів у молозиві і крові. Дослідження проводились на 40 свиноматках, розділених на дві групи за типом годівлі, тобто контрольної групи (К) та досліджуваної групи (Д), якій згодовували суміш 39 \% ферментованого після екстракції шроту ріпака (ШР) замість екстрагованого шроту сої. Дослідження розпочато після підтвердження супоросності свиноматок методом ультразвуку (УЗ) (близько 3 тижнів вагітності) та закінчено на 27 день лактації (відлучення поросят).

Ферментація ШР після екстракції є необхідним засобом для редукції анти-кормової субстанції (фітинового фосфору) у комбікормі та стимулювання імунітету, що, відповідно, впливає на якість молозива у свиноматок, які отримують корм 3 ферментованими компонентами, зменшуючи, таким чином, розвиток діареї та смертності поросят. Отримані результати підтверджують позитивний вплив ферментованих компонентів на показники продуктивності, що призводить до збільшення кількості поросят у виводку та їх маси на 28 день життя, а також на стимуляцію імунної системи, впливаючи на секрецію імуноглобулінів IgG та IgA свиноматок та поросят. Застосування ферментованого після екстракції ШР у кормових сумішах для свиноматок у період супоросності та лактації також позитивно впливає 
на використання мінеральних компонентів: фосфору, кальцію, міді та заліза з кормових сумішей.

Ключові слова: СВИНОМАТКА, ФЕРМЕТОВАНИЙ ПІСЛЯ ЕКСТРАГУВАННЯ ШРОТ РІПАКА, ПРОДУКТИВНІСТЬ, КРОВ, МОЛОЗИВО.

\title{
EFFECTIVENESS USE FERMENTED POST-EXTRACTION RAPESEED MEAL IN THE FEEDING OF SOWS
}

\author{
Czech Anna, Kiesz Martyna, Kłos Sylwia \\ Department of Biochemistry and Toxicology, Faculty of Biology, Animal Sciences \\ and Bioeconomy, University of Life Sciences in Lublin, \\ 13, Akadamicka str. 20-950 Lublin, Poland
}

\section{S U M M A R Y}

The aim of the study was to assess the effectiveness of fermented post-extraction rapeseed meal in diets for sows, during pregnancy and lactation period, on the basis of growth performance, selected immunological parameters, and the concentration of mineral elements in blood and colostrum.

The experiment was carried out on 40 sows, were divided into two groups: control (K) and experimental (D) fed mixtures containing $9 \%$ of fermented post-extraction rapeseed meal (RM) replacing the post-extraction soybean meal. The experiment started on the day of confirmed of pregnancy with ultrasound (USG) (about pregnancy at 3 weeks) and ended on the 27th day of lactation (weaning piglets).

Fermentation of RM is effective way to reduce anti-nutrients (phytate phosphate) in compound feeds as well as to stimulate the immune system, which improves the quality of colostrum and health of piglets, reducing diarrhoea severity and mortality.

The research has confirmed that fermented feed components are highly suitable in growth performance leading to growth the number of piglets in the litter and weight of the litter at 28 days of age, as well as stimulation of the immune system, influence, among others, for the secretion of secretory IgG and IgA immunoglobulins in sows and piglets. The fermentation process will also enable better utilization of protein feedstuffs of native origin in pig diets. The use of fermented rapeseed meal in diets for sows during pregnancy and lactation will also enable better utilization of minerals, i.e. phosphorus, calcium, copper and iron from feed mixtures.

Keywords: SOWS, FERMENTED POST-EXTRACTION RAPESEED MEAL, PRODUCTION EFFECTS, BLOOD, COLOSTRUM.

\section{I T E R A T U R A}

1. Zhang, T., Liu, L., Piao, X. S. Predicting the digestible energy of rapeseed meal from its chemical composition in growing-finishing pigs. Asian-Australasian Journal of Animal Sciences. 2012. - Vol. 25, - P. 375-381.

2. Yamada, Y., Iwasaki, M., Usui, H., Ohinata, K., Marczak, E. D., Lipkowski, A. W., Yoshikawa, M. Rapakinin, an anti-hypertensive peptide derived from rapeseed protein, dilates mesenteric artery of spontaneously hypertensive rats via the prostaglandin IP receptor followed by CCK1 receptor. Peptides. 2010. - Vol. 31, No 5, - P. 909-914.

3. Couto, S.R., Sanroman, M.A. Application of solid-state fermentation to food industry - A review. Journal of Food Engineering. 2006. - Vol. 76, - P. 291-302.

4. Dord-evic', T. M., Šiler-Marinkovic', S.S., Dimitrijevic'-Brankovic', S.I. Effect of 
fermentation on antioxidant properties of some cereals and pseudo cereals. Food Chemistry. 2010. Vol. 119, No 3, - P. 957-963.

5. Blaabjerg, K., Carlson, D., Hansen-Møller, J., Tauson, A.H., Poulsen, H.D. In vitro degradation of phytate and lower inositol phosphates in soaked diets and feedstuffs. Livestock Science. 2007. - Vol. 109, - P. 240-243.

6. Jørgensen, H., Sholly, D., Pedersen, A.Ø., Canibe, N., Knudsen, K.E.B. Fermentation of cereals - Influence on digestibility of nutrients in growing pigs. Livestock Science. 2010. - Vol. 134, No 1-3, - P. 56-58.

7. Grela, E.R., Skomiał, J., Zalecenia żywieniowe i wartość pokarmowa pasz dla świń. Instytut Fizjologii i Żywienia Zwierząt PAN, Jabłonna, 2015.

8. AOAC. Official Methods of Analysis. AOAC International, Gaithersburg, 2000, USA.

9. Oberleas, D. The determination of phytate and inositol phosphates. In: Methods of biochemical analysis. 1971. - Vol. 20, - P. 87-101.

10. Taylor, K.A. A simple colorimetric assay for muramic acid and lactic acid. Applied Biochemistry and Biotechnology. 1996. - Vol. 56, No 1, - P. 49-58.

11. PN-ISO 10633-1:2000. Microbiology of the food chain - Horizontal method for the enumeration of microorganisms - Part 2: Colony count at 30 degrees $\mathrm{C}$ by the surface plating technique.

12. Fiske, C.H., Subbarow, Y. The colorimetric determination of phosphorus. Journal of Biological Chemistry.1925. - Vol. 66, No 2, - P. 375-400.

13. Xu, F.Z., Zeng, X.G., Ding, X.L. Effects of replacing soybean meal with fermented rapeseed meal on performance, serum biochemical variables and intestinal morphology of broilers. Asian-Australas Journal Animal Science. 2012. - Vol. 25, No 12, - P. 1734-1741.

14. Tripathi, M.K., Mishra, A.S. Glucosinolates in animal nutrition. A review. Animal Feed Science and Technology. 2007. - Vol. 132, - P. 1-27.

15. Wang, R., Shaarani, S.M., Godoy, L.C., Melikoglu, M., Vergara, C.S., Koutinas, A., Webb, C. Bioconversion of rapeseed meal for the production of a generic microbial feedstock. Enzyme and Microbial Technology. 2010. - Vol. 47, - P. 77-83.

16. SchoÈne, F., Leiterer, M., Hartung, H., Jahreis, G., Tischendorf, F. Rapeseed glucosinolates and iodine in sows affect the milk iodine concentration and the iodine status of piglets. British Journal of Nutrition. 2001 - Vol. 85, - P. 659-670.

17. Bontempo, V., Sciannimanico, D., Pastorelli, G., Rossi, R.., Rosi, F., Corino, C. Dietary conjugated linoleic acid positively affects immunologic variables in lactating sows and piglets. Journal of Nutrition. 2004. - Vol. 133, No 4, - P. 817-824.

18. Scholten, R.H., van der Peet-Schwering, C.M., Verstegen, M.W., den Hartog, L.A., Schrama, J.W., Vesseur, P.C. Fermented co-products and fermented compound diets for pigs: a review. Animal Feed Science and Technology. 1999. - Vol. 82, No 1 2, - P. 1-19.

19. De Lange, C.F.M., Pluske, J., Gong, J., Nyachoti, C.M. Strategic use of feed ingredients and feed additives to stimulate gut health and development in young pigs. Livestock Science. 2010. - Vol. 134, No 13 , - P. 124-134.

20. Nagler-Anderson, C.,Terhorst, C., Bhan, A.K., Podolsky, D.K. Mucosal antigen presentation and the control of tolerance and immunity. Trends in Immunology. 2001. - Vol. 22, No 3, - P.120-122. 4.

21. Cai, C.J., Cai, P.P., Hou, C.L., Zeng, X.F., Qiao, S.Y. Administration of Lactobacillus fermentum 15007 to young piglets improved their health and growth. Journal of Animal and Feed Sciences. 2014. - Vol. 23, - P. 222-227.

22. Czech, A., Grela, E.R., Mokrzycka, A., Pejsak, Z. Efficacy of mannanoligosaccharides additive to sows diets on colostrum, blood immunoglobulin content and production parameters of piglets. Polish Journal of Veterinary Sciences. 2010. - Vol. 13, No 3, - P. 525-531.

23. Pluske, J.R., Kim, J.C., Black, J.L. Manipulating the immune system for pigs to optimise 
performance. Animal Production Science. 2018. - Vol. 58, No 4, - P. 666-680.

24. Reddy, K.E., 'Jung, H.J., Kim, D.W., Cho, K.H., Cho, S.B., Kim, S.H., Jeong, J.Y., 'Lee, S.D. Effects of freeze dried placenta supplementation in pregnant sows on reproductive performance, colostrum biochemical composition and piglet growth rate. Journal of Agriculture and Life Science. 2018 - Vol. 52, No 1, - P. 53-60.

25. Salmon, H., Berri, M., Gerdts, V., Meurens, F. Humoral and cellular factors of maternal immunity in swine. Developmental and Comparative Immunology. 2009. - Vol. 33, - P.384-393.

26. Rooke, J.A., Bland, I.M. The acquisition of passive immunity in the new born piglet. Livestock Production Science. 2002. - Vol. 78, - P. 13-23.

27. Mizumach, K., Aoki, R., Ohmori, H., Saeki, M., Kawashima, T. Effect of fermented liquid diet prepared with Lactobacillus plantarum LQ80 on the immune response in weaning pigs. Animal. 2009. - Vol. 3, No 5, - P. 670-676.

28. Shi, C., He, J., Yu, J., Yu, B., Mao, X., Zheng, P., Huang, Z., Chen, D. Amino acid, phosphorus, and energy digestibility of Aspergillus niger fermented rapeseed meal fed to growing pigs. Journal of Animal Science. 2015. - Vol. 93, No 6, - P. 2916-2925.

29. Tomaszewska, E., Muszyński, S., Dobrowolski, P., Kamiński, D., Czech, A., Grela, E.R., Wiącek, D., Tomczyk-Warunek, A. Dried fermented post-extraction rapeseed meal given to sows as an alternative protein source for soybean meal during pregnancy improves bone development of their offspring. Livestock Science. 2019. - Vol 224, - P. 60-68, DOI:10.1016/j.livsci.2019.04.009

30. El-Batal, A.I., Karem, H.A. Phytase production and phytic acid reduction in rapeseed meal by Aspergillus niger during solid state fermentation. Food Research International. 2011. - Vol. 34, No 8 - P. 715-720.

31. Stein, H.H., Sauber, T.E., Rice, D.W., Hinds, M.A., Smith, B.L, Dana, G., Peters, D.N., Hunst, P. Growth Performance and Carcass Composition of Pigs Fed Corn Grain from DAS-Ø15Ø71 (Herculex I) Hybrids. The Professional Animal Scientist. 2009. - Vol. 25, No 6, - P. 689-694.

32. Shi, C., He, J., Wang, J., Yu, J., Yu, B., Mao, X., Zheng, P., Huang, Z., Chen, D. Effects of Aspergillus niger fermented rapeseed meal on nutrient digestibility, growth performance and serum parameters in growing pigs. Animal Science Journal. 2016. - Vol. 87, No 4, - P.557-563.

33. Iqbal, S., Younas, U., Chan, K.W., Sarfraz, R.A., Uddin, M.K. Proximate composition and antioxidant potential of leaves from three varieties of Mulberry (Morus sp.): a comparative study. International Journal of Molecular Sciences, 2012. - Vol. 13, - P. 6651-6664.

34. Czech, A., Grela, E.R. Biochemical and haematological blood parameters of sows during pregnancy and lactation fed the diet with different source and activity of phytase. Animal Feed Science and Technology. 2004. - Vol. 116, No 3-4, - P. 211-223.

35. Missotten, J.A.M., Michiels, J., Degroote, J., De Smet, S. Fermented liquid feed for pigs: an ancient technique for the future. Journal of Animal Science and Biotechnology. 2015. - Vol. 6, No $4 \mathrm{https}: / /$ doi.org/10.1186/2049-1891-6-4

36. Juanpere, J., Pe'rez-Vendrell, A.M., Angulo, E., Brufau, J. Assessment of Potential Interactions Between Phytase and Glycosidase Enzyme Supplementation on Nutrient Digestibility in Broilers. Poultry Science. 2005. - Vol. 84, - P. 571-575.

37. Kim, J.C., Simmins, P.H., Mullan, B.P., Pluske, J.R. The effect of wheat phosphorus content and supplemental enzymes on digestibility and growth performance of weaner pigs. Animal Feed Science and Technology. 2005. - Vol. 118, - P. 39-152.

38. Czech, A., Stachyra, K., Woźnica, A. Influence of feed enzymes on content of mineral elements in sows milk and pigs blood plasma. Annales Universitatis Mariae Curie-Skłodowska Lublin-Polonia Sectio EE Zootechnica, 2011. - Vol. 29, No 4, - P. 22-32.

Recenzia - Rozempolska-Rucińska Iwona, dr hab. Profesor, Wydzial Biologii, Nauk o Zwierzętach i Biogospodarki UP w Lublinie. 